\title{
Works in Favor of Extraction: Labor in Land-Use Competition
}

\author{
Anke Schaffartzik 1,2 (D) \\ 1 Institut de Ciència i Tecnologia Ambientals (ICTA), Universitat Autònoma de Barcelona (UAB), \\ 08193 Bellaterra, Spain; anke.schaffartzik@uab.cat \\ 2 Institute of Social Ecology (SEC), University of Natural Resources and Life Sciences (BOKU), \\ 1070 Vienna, Austria
}

Received: 30 April 2018; Accepted: 8 June 2018; Published: 11 June 2018

\begin{abstract}
Despite their negative social and environmental consequences, claims to land for resource extraction are dominantly asserted under conditions of land-use competition. The 'success' of the extractive expansion relies on very specific labor arrangements. Through dispossession and unfulfilled promises of long-term employment, an overabundance of labor (or employment gap) is generated at extractive sites. Poverty is exploited in order to sustain business as usual: environmental degradation, low average wages and high wage inequality, and abysmal working conditions. In resolving global land-use competition for sustainability transformations, it is necessary to address labor arrangements as a mechanism through which the claim to land for resource extraction is asserted.
\end{abstract}

Keywords: abundance of labor; appropriation; claims to land; dispossession; employment; resources

\section{Introduction: International Patterns of Resource Use and Competing Claims to Land}

In the high-income countries and wealthy segments of the global population, we 'enjoy' a lifestyle that is based on the appropriation of land-based resources in all corners of the world. The more we consider the implications of this lifestyle and the difficulty in opting out of it, the less we may find that it is something truly enjoyable. Our material consumption may not be the underlying cause of claims to land and labor at extraction sites, but it does make us actors in the international competition over land use. Additionally, this makes us beneficiaries of the claim to land for resource extraction.

During the unprecedented global rise of resource use over the last decades, claims to land for resource extraction have overwhelmingly been asserted over other claims-for subsistence farming, for conservation, and for settlements including the infrastructure servicing them. The extractive expansion is particularly pronounced in South America's Andes and Amazon [1] regions and is expected to spread rapidly throughout Sub-Saharan Africa [2] while initiatives are underway in Europe and North America to revive mineral extraction [3,4]. Sustained high material demand in the wealthy countries and rising demand in the emerging economies are commonly offered by way of explanation for the global surge in resource extraction $[5,6]$. Growing markets are an incentive to expanding production for economic reasons [7,8], and the extractive expansion may play an important role in safeguarding vested political interests through the control over people and land it facilitates [9].

International inequality in access to, and use of, material resources [10] has made the "unlimited appropriation of resources" [11] by the richest segments of the human population possible within the confines of our planetary boundaries [12]. Mature industrialized and high-income economies rely heavily on resource imports from other parts of the world [5], especially from the middle-income emerging economies [13]. These patterns of resource use rely on continuous expansion of extraction, a practice that may be strongly contested locally [14]. The claims of social movements to leave known 
resources untouched $[15,16]$ have been echoed by research finding that restricting extraction may be the only way to curb the environmental impact $[17,18]$.

Most of the world's wealthy countries compensate the previous depletion of key resources on their territory (or, less commonly, protect their domestic resource base) by meeting final demand through imports. The global socio-ecological impact of high economic income is much greater than it may appear at the national level $[19,20]$ with global appropriation of resources far exceeding apparent domestic resource consumption [21]. Especially in the middle-income countries, extraction and production are increasingly driven by foreign final demand $[13,22]$. Regions of the world where food is in short supply may find that their agricultural production is geared towards non-food biomass (especially for fiber and fuel) [23]. The extraction and processing of resources into material goods requires human labor so that the appropriation of resources via trade coincides with the appropriation of labor [11]. Land grabs-the large-scale international investments into land for resource extraction $[22,24]$ - are simultaneously claims to the energy and the human labor needed to make use of the land $[25,26]$. Land grabs tend to originate from countries of higher income and target lower income countries. Additionally, in general, high-income economies claim more labor, especially low-wage, low-skilled labor, through their imports than they supply through their exports $[27,28]$. World-systems theory has proposed that the global economy can be characterized by unskilled, low-wage work associated with resource extraction in the economies of the periphery exchanged for high-skilled work in sectors with high-value added in the core economies [29,30]. Competing claims to land can be identified not only by their intended land use-mining or large-scale agricultural production, conservation or smallholder farming, for example [9,31-33] — but also by the appropriation of labor associated with the particular form of land use.

If competing claims to land are simultaneously competing claims to labor, then the dominance of the extractive expansion must coincide with spreading extractive labor arrangements. These arrangements-because they are a precondition to further extractive expansion-explain the overwhelming 'success' of claims to land for resource extraction. Through the immense historical and current resource appropriation and use by the world's wealthy countries, the assertion of this claim threatens human survival, disproportionately affecting the poor [34,35]. I understand the labor arrangements that aid extractive expansion to be part of the problem, to re-inforce socially and ecologically unsustainable practices.

\section{Literature Review: Resources and Labor in Extractive Expansion}

Much research has already been done on labor related to resource extraction at specific sites and for specific resources. My aim was to synergize general insights on labor arrangements in resource extraction, in particular as they relate to competing land-use claims.

\subsection{Literature Selection}

I conducted a broad topical search of academic publications on labor in resource extraction using the following arguments in the Web of Science application (http: / apps.webofknowledge.com, last accessed 27 April 2018):

("resource extraction" OR "extractive frontier" OR "extractive expansion" OR extractivism OR "extractive economy") AND (labor OR labour OR employment OR worker* OR wage* $\left.\mathrm{OR} \mathrm{job}^{*}\right)$

This search yielded 145 publications out of which 60 were directly relevant to my hypothesis. The majority of search results did not apply to my hypothesis either due to their historic focus or for semantic reasons. The specific labor arrangements that made the extraction and processing of key resources possible historically are undoubtedly relevant to the point that they have enabled (or necessitated) the development of the political and economic systems in which we now live [36-38]. I focused my review on extractive expansion in the late 20th and early 21 st century as a period 
of unprecedented growth in global material extraction $[5,6,39]$ and of intensified competition over resources, including land [31-33,40], on a physically limited planet [34]. Within a topic-resource extraction and labor-that I could not have done justice to within a single article, I identified a temporal focus especially relevant to the Land-Use Competition Special Issue to which my work contributes. Next to the exclusion of historical research, I also excluded publications if one of the arguments in the second topical search (connected by AND, see above) appeared in the publication but was not used in relation to the extractive industry. Several authors, for example, referred to the "employment" of methods and/or to their own "employment" in their work.

In addition to the Web of Science search results, I reviewed literature that had originally led me to develop the topic. Most of this research is cited in Sections 1 and 2 of this article. I also followed up on work cited in the 60 articles forming the core for my review.

\subsection{The Problem Bias}

The research I reviewed tends to be problem-driven, covering cases of extractive expansion that at least one person (the researcher) identified as problematic. My survey did not yield evidence for extractive expansion as beneficial to the local environment and population. This does not mean that such cases may not exist, but that they have not enlisted the attention of researchers to the extent that social hardship and environmental destruction in the wake of extraction have. After the initial hypothesis was formed, I was prone to search for supporting (rather than negating) evidence, adding a second layer of bias to my analysis.

The problem bias, however, does not impede the interpretability of my results. I do not discard the possibility that extractive expansion may occur in a manner beneficial to the local population. First, I do document that this has, so far, not been brought into evidence while negative impacts for the local population abundantly have. Second, the meta-analysis of labor in resource extraction suggests that labor arrangements play a functional role in asserting extractive claims to land. This is an observation that would have to be corrected for extractive expansion that can be maintained without an employment gap and the ensuing competition among workers. In light of the problem bias, I do not conclude that resource extraction always relies on the labor arrangements I have identified. Resource extraction noted for its adverse environmental and/or social impact on the lives of millions of people does rely on these labor arrangements.

\section{Extractive Expansion Creates and Needs an Employment Gap}

Where claims to land for resource extraction (especially agriculture, including plantations, and mining) are asserted, they are directly associated with the dispossession of people from land. This often constitutes the loss of the one resource central to these people's livelihoods. As a result, people become dependent on wage-based employment as a source of income in order to meet their subsistence needs via the market. The wage employment created at the sites of extraction, however, is not sufficient to provide alternative incomes. Employment additionally tends to be seasonal or temporary. Labor migration to the extraction sites increases the number of people in search of employment. A significant employment gap, also referred to as an (over-)abundance of labor, is the result. This gap, along with the competition it causes among workers, makes it possible for the extractive expansion to conduct 'business as usual' of low average wages and high wage inequality in precarious and abysmal working conditions.

\subsection{Dispossession Leads to Need for Employment}

The expansion of resource extraction is one particular claim to land use asserted while other claims are denied. Large-scale tree plantations and other large-scale agricultural expansions, mining sites, and the secondary infrastructure development associated with extraction are land-based activities, commonly requiring the dispossession of local people from land [22,26,41,42]. Existing political power relations-manifest in legislation and the rights that are acknowledged, the ability to coerce, and in the 
inability of the local population to compete in the capitalist market-enable dispossession through a range of different mechanisms [43]. Examples include refusal to acknowledge traditional land tenure systems [44], violent expulsions [45], and smallholder agricultural production that cannot compete with the commodity production on large land holdings, in particular due to scale effects [46-48]. In Indonesia, people may have cared for and based their livelihood on a patch of land for generations only to find that a day-old piece of paper declares a company they have never heard of to be the rightful owner of their land [44]. In the Philippines, mining companies could count on para-military forces to carry out abusive attacks on the local population and assassins silenced the most vocal protesters [45]. In Guatemala, peasants have been coerced into selling their land at prices dictated by agri-businesses $[46,47]$. All over Asia, the removal of tariffs on imported goods and government subsidies for agriculture have forced farmers to compete with commodity prices so low that they preclude the possibility of making a living [48]. Even where land is not claimed for extractivist expansion directly, local populations may be forced to search for a new basis for their livelihoods if vital resources are comprised by nearby extractive industries. Large-scale agriculture as well as mining may drain and/or pollute local water supply, for example $[49,50]$, making previous cultivation impossible and/or forcing people to purchase safe drinking water.

Dispossession from land is not limited to claims to land for extraction. Conservation has recently become a wide-spread reason for exclusion [48], affecting millions of people, as many as 8.5 million by 2005 [51]. In an attempt at global environmental conservation supported by governments and non-governmental organizations, people are locally evicted from the land that constitutes their livelihood resource [48]. The link to land claimed for extraction is given for those conservation measures that compensate environmental degradation elsewhere: The United Nations' Reducing Emissions from Deforestation and forest Degradation (REDD+) mechanism allows wealthy countries to pay developing countries to protect their forests, providing an incentive for distantly-made and locally-mediated claims to in-use land [52].

The loss of land (or of other resources) and the decline in local prices for agricultural commodities force people to search for wage labor, either in the local extractive industry or through migration, often to urban areas [53]. Sometimes, the blow from original dispossession from land is softened by the promise of or hope for employment in the extractive industry [42,54].

\subsection{Employment in Extraction is Precarious}

Extractive projects do not consistently offer the employment needed by (or acceptable to, see Section 3.5) the local population. All forms of resource extraction have experienced mechanization which allows for the substitution of labor by capital through the use of fossil-fueled machines [45,55]. Persisting high labor requirements in the extractive expansion for both agriculture and mining tend to be temporary and/or seasonal and coincide with (1) the preparation for extraction and (2) harvest or mining peaks.

Newly-built energy and transport infrastructure enable the expansion of the resource frontier into previously inaccessible areas [56]: Deforestation and the construction of roads are labor-intensive paths to site-access. Large agricultural developments require especially high labor input in preparing the extraction site, again, through deforestation, as well as in the construction of buildings (some shelter for laborers, storage of machinery and, especially, silos) and further transport infrastructure [57]. The building of roads to the mining site, as well the initial construction of the mine (both also potentially associated with some form of land clearing), are also associated with some of the highest labor requirements in non-agricultural extraction [58,59].

Once (extraction) infrastructure is established, the employment associated with mechanized mineral extraction tends to be low $[60,61]$ with some temporary intermittent rise in labor demand [62] for the construction of drainage canals [42] or the drilling of new wells [63], for example, especially when high commodity prices incentivize production peaks [64]. For mineral extraction, the prevalence of precarious employment has been documented in particular in the global North. The mechanization 
of agriculture has greatly decreased the labor required [65], although the harvest of many crops, especially on uneven or rocky terrain and of crops that do not easily allow for mechanized harvest, continues to require high labor input seasonally. During harvest season, labor demand for transportation, maintenance of roads, and in the storage of harvested crops may also be required. The predominance of precarious, temporal, or seasonal labor has been observed on Colombian coffee plantations [66], in sugar cane cropping in Guatemala [67], and the expansion of soy monocultures in Bolivia [65], as well as for natural resource extraction in Latin America, in general [68,69].

\subsection{Migration, Long-Distance Commuting, and Remote Work Add to the Labor Force}

While the dispossession of the local population from their land already generates need for employment, labor migration increases the numbers of people looking for work at extraction sites.

Prevailing poverty and economic distress push workers towards newly developed mines or plantations in search of a small share of the resource riches. In the African mining boom, settlements and towns populated by those seeking employment are rapidly sprouting close to extraction sites [17]. Mechanisms are in place to 'encourage' this labor migration: next to government-sponsored resettlement programs, for example in Indonesia [70] and Liberia [57], companies may actively seek migrant workers temporary contracts for whom they favor over permanent contracts for residents $[41,42,67]$. Their status as migrants negatively affects working conditions beyond the duration of their contracts for these workers. International labor migration may allow for labor terms and conditions (in countries of the global North, as well) that would not hold up to local legislation failing to ensure the safety of the employees $[48,71]$. Workers may be forced (often through the confiscation of their documentation and, thus, through forcing them to remain at the site of extraction) to work for free until they have paid off the debt incurred through the costs of their travel to the extraction site and the processing of their paperwork [72].

In countries of the global North, labor migration tends to be more strongly associated with financial benefits and is commonly referred to as long-distance commuting [58,73], allowing to semantically differentiate these dynamics from the plight of migrants in the global South. Temporary settlements for long-distance commuting workers are a common feature in the extractive industries of the global North $[58,73,74]$ with comparatively high wages making this form of employment attractive for those who do not have binding obligations at their place of residence (dependent family members, for example). Competitive wages associated with long-distance commuting and not the economic distress of migrant workers from the global South are perhaps also what Leite and Weidmann [75] had in mind when they described in a report for the International Monetary Fund how resource booms "lure workers ... away from other sectors" (p. 8).

However, even in the global North, the jobs created often do not lead to increased income at the site of extraction and, overall, long-term income benefits are slight [63]. High-wage managerial work associated with resource extraction is increasingly performed remotely, usually from business headquarters in the rich industrialized countries. This pattern can be observed not only for extraction in the global South $[76,77]$ but also in the North $[55,62,73]$. This may coincide with the increased use of labor from elsewhere in the extractive operation $[55,76]$.

Through the impacts of labor migration, the overabundance of labor at extraction sites caused by the coupling of dispossession from livelihood resources with low long-term employment opportunities is transformed into a systematic employment gap in extractive expansion.

\subsection{The Employment Gap in Extractive Expansion}

The extractive expansion does not systematically offer sufficient possibilities for long-term alternative incomes to absorb the (new) needs of the local population [42,65]. While employment at extractive sites may be high during initial development, this employment is temporary. The income opportunities advertised and anticipated in conjunction with resource extraction do not materialize, leading to a growing employment gap as more people migrate towards the site (Figure 1). Tanya Li [48] 
describes the labor force represented by the local population at the site of extraction as "surplus" to the requirements of capital accumulation", critically discussing the description of population as "surplus", noting that she uses the term "to provoke some hard thinking". The gap between income needed and attainable at sites of extractive expansion is already large. In China, for example, even the fast-growing manufacturing sector could not absorb hundreds of millions of peasants dispossessed from their land. For those who did find employment, it was associated with migration to urban production centers where their legal status is precarious [78]. A study by Zockun [79] cited by Fearnside [80] already found that in Brazilian Amazon in the 1970s, 11 small farmers were displaced for every single job created on soybean plantations. The expansion of these monocultures continues to displace or bar other forms of land use, including subsistence agriculture, while generating low employment opportunities [68].

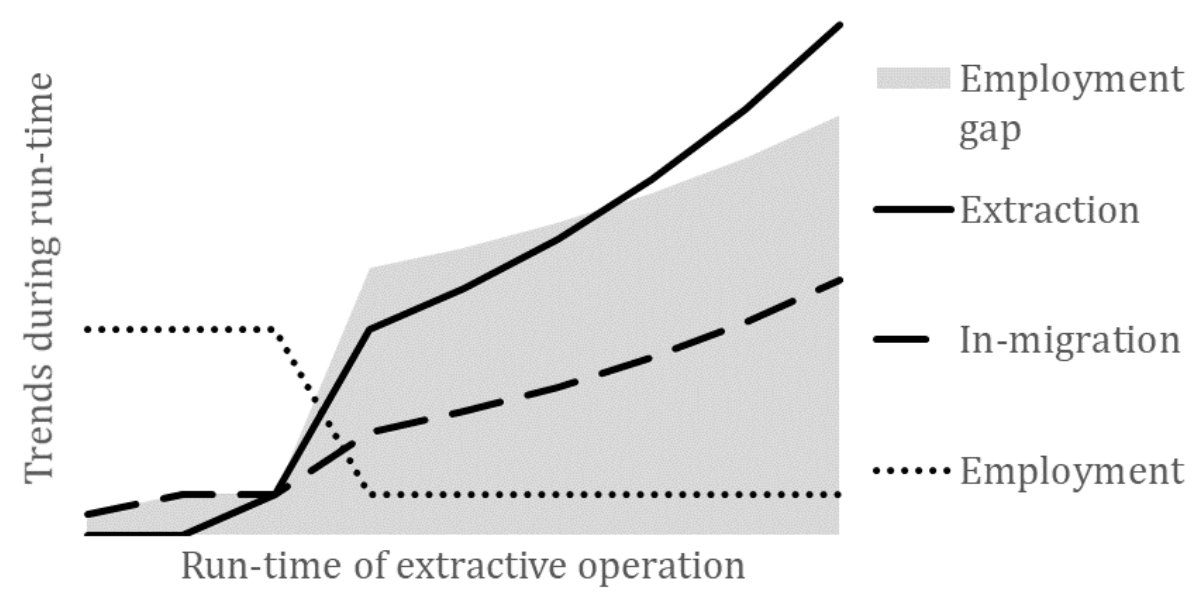

Figure 1. The employment gap is the result of low demand for labor once the extractive operation has been established and of labor migration drawn to the site by the perceived possibility for income from resource extraction, as well as by government and corporate initiatives. This figure is a conceptual sketch of trends over time.

Even though dispossession is not very widespread in the global North (mainly because it has already occurred in the past), the general assessment is that the jobs created in extractive industries lag behind what was anticipated or advertised [81] and do not justify the environmental and social impacts of extractivist expansion [82]. Wages in the extractive sector fall below the reproductive costs of households and must be subsidized through unpaid reproductive work (almost exclusively by women) [60]. Even where wages in the mining sector are higher than average, so few new high-wage jobs are created that they have little to no impact on poverty and unemployment $[61,83,84]$ and may lead to rising inequality around extraction sites $[74,85]$.

Little evidence is available to support the promise that the initial development of extractive activities will lead to the subsequent/parallel development of linked industries that will continue to provide income and employment after extraction: Not, for example, in Bolivia [65], in North America [64,86], India, or even in China [48].

\subsection{Enabling Business as Usual}

The employment gap in extractivist expansion and the mechanisms through which it is created is not merely an unintended by-product in the pursuit of profit. Instead, this gap is a prerequisite for business as usual in the extractive industry. The employment gap leaves a significant share of the local population dependent on the extractive companies for meeting their livelihood needs, cementing the power relations between the two groups of actors [87].

Dispossession of people from their land (Section 3.1) is clearly not only a means to gain access to the land, but also to the workforce (even if it is over-abundant). In fact, so long as it does not alleviate 
the need for employment, access to land may be (informally) granted. Low-level subsistence land use may allow for the reproduction of labor in spite of low wages and high unemployment $[53,76]$, or unpaid work may be required of the population in return for special permits to continue living in otherwise claimed areas (for example, on state forest land) [50].

To people in need of wage income, even temporary employment is, of course, better than no employment [88] and the overabundance of labor plays a role in enabling companies to maintain hazardous, unpaid, and slave-like work at sites of resource extraction [89]. Abysmal working conditions have been documented in sugarcane production in Brazil [90] and plantation agriculture in Guatemala [46], for example. In British Columbia, Canada, resource-extraction booms have been shown to have detrimental health and social impacts on young people living in an extractive community [91]. In a case study of coal mining in Australia, high income inequality and mainly low- or unskilled work, paired with low education levels, were found to prevail in communities depending on mining for employment [74]. Generally, mining has been found to be more likely to increase than decrease poverty [92] and poverty is generally likely to be high in resource-dependent areas [55], even in the global North [86].

Even under these circumstances, workers have been brought into fierce competition for employment in the extractive industries, allowing companies to select workers according to their exploitability in the South [67], as well as the North [62]. This situation is exasperated by the increasing prevalence of sub-contracting, especially in the mining industry, whereby the main extractive company contracts a second company to provide labor at the extraction site. These workers are not employed by the mining company, may have significantly worse contract conditions, and even earn only half of what company employees earn for the same work [93].

Although the incomes made available are by no means sufficient as the basis for livelihoods, the promise of employment is still used as an argument in favor or extractive expansion by governments and businesses $[60,88,94,95]$. At extraction sites where few high-income jobs are created, but the majority of the local population does not economically benefit (a situation which is common, see Sections 3.2 and 3.4), rising prices (especially for housing) may force low-income or unemployed residents to move somewhere affordable. This may lead to a reduction of the unemployment rate, masking the underlying situation [74], and further protecting the status quo.

\section{In Land-Use Competition, Extractivist Expansion Overrides Competing Claims}

Through dispossession of people from their livelihood resources, through insufficient opportunities for alternative incomes, and by structuring labor in such a way that the overabundance of cheap labor allows for precarious, hazardous, and slave-like working conditions to persist, the manner in which extractivist expansion occurs safeguards its own continuity. The 'success' of extractive claims to land in land-use competition are, in part, due to the specific extractive labor arrangements.

Resource extraction enables economic growth in rural areas based on a system of production in which capital largely substitutes for labor and the need for manual work is largely temporal or seasonal. Despite lip service to the contrary, the local populations, especially those dispossessed from their land, do not stand to benefit in the long-term from extractive expansion. Yet, even those not employed in the extractive industries are not really "surplus" from the point of view of the extractive enterprise [48] because the overabundance of cheap labor they represent is instrumental in enabling business as usual, in allowing the precarious, unpleasant or even abysmal working conditions at extraction sites around the world to persist.

Through its labor arrangements, the extractive expansion is executed across levels of scale and cements future through present extraction. Both mechanisms are relevant to the 'success' of claims to land for resources extraction. 


\subsection{Extractive Claims across Levels of Scale}

Claims to land for extractive expansion have additional leverage over other claims through the execution of this expansion across levels of scale. The combination of remote labor, especially in managerial decisions $[62,73,77]$ and temporal employment of workers with vastly different statuses $[55,76]$ in the face of a local employment gap (Section 3.4), removes the original claim to land from its execution and reinforcement. Extractive companies making a profit, commuting high-wage workers, seasonal low-wage laborers, and displaced local populations all operate at different scales, making it difficult to contest claims without access to the level at which they are made [96].

The claim to land for resource extraction is more easily asserted because, through its labor arrangements, it is executed across levels of scale. The interests of the local population - dispossessed from its land, in need of alternative income-are at odds with interests of others profiting from this situation, through access to resources and income [48]. Here, the spatial disconnect between land-use change and its drivers [97] is not the unintended by-product of globalized production and consumption, but plays a functional role favoring a particular claim.

\subsection{Extraction Legacy}

Any previous decision for resource extraction provides some inertia for future resource extraction (at the same and nearby sites), and labor plays an important role in this legacy effect. Extractive activities, from plantations to mines, and their accessory infrastructure, fundamentally structure the physical landscape $[45,48,98]$. This not only makes other land uses difficult, or completely bars them, but also leaves a labor force specialized in resource extraction-the effects can be seen, for example, when small-scale mining continues after the disoperation of mines, informally creating ideal conditions for renewed investments into the ceased extractive activities (e.g., [45]). In addition, at sites of resource extraction, the logic of extraction may be mainstreamed into various areas of life, including education [99]. If entire generations are prepared for life in an extractive society, this cements 'support' for extractive claims to land.

Even the emerging transition to renewable energy sources may fall solidly into the logic of extraction and the extractive labor arrangements accompanying it. Whether flex crops are grown for biofuel production [22,24], vast amounts of wind energy are harvested [100] or rivers are dammed to generate hydroelectricity [101], large-scale renewable energy projects depend on the dispossession of people from their land, offering only temporary employment and income for the local population, and do not generate opportunities for alternative livelihoods.

\subsection{From Competition to Conflict}

Given the detrimental (expected) impacts of many forms of resource extraction on the local population and on future generations, we might initially expect higher rates of extraction to face greater opposition and to increasingly give rise to manifest conflict. It seems natural for Fabiana $\mathrm{Li}$ [102] to note, for example, "The lack of jobs and the loss of land have made mining conflicts part of daily life [in Peru]". Through its labor arrangements, the expansion of resource extraction has left local people dependent on the extractive industry and excluded them from other possible livelihoods to such an extent that these arrangements, themselves, pose a formidable barrier to contesting the established power relations. The high numbers of manifest conflicts over land use [14] are all the more remarkable.

\section{Conclusions}

The global surge in material resource extraction is commonly associated with growing material demand associated with high and increasing wealth. Yet it is poverty on which extractive expansion thrives, from Canada to Colombia and from coal to coffee. For the broad geographic and material scope covered by the literature reviewed in this analysis, the employment gap-the over-abundance of 
cheap labor around mines and plantations-sustains extraction with its low average wages, high wage inequality, and abysmal working conditions.

Poverty and the dispossession of people from their livelihood resource, especially at extractive sites, generates an urgent need for alternative income. This need is exploited as the justification for environmental degradation that is cloaked in the promise of employment. This need and the ensuing competition for scarce income allows for extractive operations to sustain their socially and environmentally hazardous business as usual. Under conditions of land-use competition, poverty allows one claim to prevail over many others. The assertion of this claim through labor arrangements is the assertion of power more than it is material necessity.

In resolving global land-use competition for sustainability transformations, how claims are asserted may be as important as to which claims are asserted. Additinoally, the labor arrangements in extraction appear to be an important element in the dominance of this claim. A large share of the material demand met by extractive expansion corresponds to our consumption in globally wealthy population segments and rich countries. Material wealth relies on the appropriation of both land and labor. In order to intervene into inherently unsustainable global extractive expansion, it is necessary to tackle the poverty that enables it. Guaranteed access to land as a livelihood resource or to a basic monetary income would give people the possibility to refuse work that exploits them and their environment.

Funding: This research received no external funding.

Acknowledgments: The author acknowledges the financial support of the Spanish Ministry of Economy and Competitiveness, through the "María de Maeztu" program for Units of Excellence (MDM-2015-0552).

Conflicts of Interest: The author declares no conflict of interest.

\section{References}

1. Bebbington, A. Social Conflict, Economic Development and the Extractive Industry: Evidence from South America; Routledge: Abingdon, UK, 2011; ISBN 978-1-136-62022-5.

2. Laurance, W.F.; Sloan, S.; Weng, L.; Sayer, J.A. Estimating the environmental costs of Africa's massive "development corridors". Curr. Biol. 2015, 25, 3202-3208. [CrossRef] [PubMed]

3. European Commission. Communication from the Commission to the European Parliament, the Council, the European Economic and Social Committee and the Committee of the Regions for a European Industrial Renaissance; European Commission: Brussels, Belgium, 2014.

4. Crooks, E. Coal's US comeback fuelled by rival. Financial Times, 26 August 2017.

5. Schaffartzik, A.; Mayer, A.; Gingrich, S.; Eisenmenger, N.; Loy, C.; Krausmann, F. The global metabolic transition: Regional patterns and trends of global material flows, 1950-2010. Glob. Environ. Chang. 2014, 26, 87-97. [CrossRef] [PubMed]

6. Schandl, H.; Fischer-Kowalski, M.; West, J.; Giljum, S.; Dittrich, M.; Eisenmenger, N.; Geschke, A.; Lieber, M.; Wieland, H.; Schaffartzik, A.; et al. Global material flows and resource productivity: forty years of evidence. J. Ind. Ecol. 2017. [CrossRef]

7. Weinberg, A.; Schnaiberg, A.; Pellow, D.N. The treadmill of production and the environmental state. In The Environmental State under Pressure; Research in Social Problems and Public Policy; Emerald Group Publishing Limited: Bingley, UK, 2002; Volume 10, pp. 15-32.

8. Gould, K.A.; Pellow, D.N.; Schnaiberg, A. Interrogating the treadmill of production: everything you wanted to know about the treadmill but were afraid to ask. Organ. Environ. 2004, 17, 296-316. [CrossRef]

9. Brad, A.; Schaffartzik, A.; Pichler, M.; Plank, C. Contested territorialization and biophysical expansion of oil palm plantations in Indonesia. Geoforum 2015, 64, 100-111. [CrossRef]

10. Griggs, D.; Stafford-Smith, M.; Gaffney, O.; Rockström, J.; Öhman, M.C.; Shyamsundar, P.; Steffen, W.; Glaser, G.; Kanie, N.; Noble, I. Policy: Sustainable development goals for people and planet. Nature 2013, 495, 305-307. [CrossRef] [PubMed]

11. Brand, U.; Wissen, M. Global environmental politics and the imperial mode of living: Articulations of state-capital relations in the multiple crisis. Globalizations 2012, 9, 547-560. [CrossRef] 
12. Rockström, J.; Steffen, W.; Noone, K.; Persson, Å.; Chapin, F.S.; Lambin, E.F.; Lenton, T.M.; Scheffer, M.; Folke, C.; Schellnhuber, H.J.; et al. A safe operating space for humanity. Nature 2009, 461, 472-475. [CrossRef] [PubMed]

13. Schaffartzik, A.; Pichler, M. Extractive economies in material and political terms: Broadening the analytical scope. Sustainability 2017, 9, 1047. [CrossRef]

14. Temper, L.; Del Bene, D.; Martinez-Alier, J. Mapping the frontiers and front lines of global environmental justice: The EJAtlas. J. Political Ecol. 2015, 22, 255-278. [CrossRef]

15. Bond, P. Social movements and corporate social responsibility in South Africa. Dev. Chang. 2008, 39, 1037-1052. [CrossRef]

16. Bridge, G. Geographies of peak oil: The other carbon problem. Geoforum 2010, 41, 523-530. [CrossRef]

17. Edwards, D.P.; Sloan, S.; Weng, L.; Dirks, P.; Sayer, J.; Laurance, W.F. Mining and the African environment. Conserv. Lett. 2014, 7, 302-311. [CrossRef]

18. McGlade, C.; Ekins, P. The geographical distribution of fossil fuels unused when limiting global warming to $2{ }^{\circ} \mathrm{C}$. Nature 2015, 517, 187-190. [CrossRef] [PubMed]

19. Bunker, S.G. Raw material and the global economy: Oversights and distortions in industrial ecology. Soc. Nat. Resour. 1996, 9, 419-429. [CrossRef]

20. Ekins, P.; Folke, C.; Costanza, R. Trade, environment and development: The issues in perspective. Ecol. Econ. 1994, 9, 1-12. [CrossRef]

21. Wiedmann, T.O.; Schandl, H.; Lenzen, M.; Moran, D.; Suh, S.; West, J.; Kanemoto, K. The material footprint of nations. Proc. Natl. Acad. Sci. USA 2015, 112, 6271-6276. [CrossRef] [PubMed]

22. Aguilar-Stoen, M. Beyond Transnational Corporations, Food and Biofuels: The Role of extractivism and agribusiness in land grabbing in Central America. Forum Dev. Stud. 2016, 43, 155-175. [CrossRef]

23. Borras, S.M.; Franco, J.C.; Isakson, S.R.; Levidow, L.; Vervest, P. The rise of flex crops and commodities: Implications for research. J. Peasant Stud. 2016, 43, 93-115. [CrossRef]

24. Borras, S.M.; Hall, R.; Scoones, I.; White, B.; Wolford, W. Towards a better understanding of global land grabbing: An editorial introduction. J. Peasant Stud. 2011, 38, 209-216. [CrossRef]

25. Borras, S.M.; Kay, C.; Gómez, S.; Wilkinson, J. Land grabbing and global capitalist accumulation: Key features in Latin America. Can. J. Dev. Stud. Can. Détudes Dév. 2012, 33, 402-416. [CrossRef]

26. Li, T.M. Centering labor in the land grab debate. J. Peasant Stud. 2011, 38, 281-298. [CrossRef]

27. Alsamawi, A.; Murray, J.; Lenzen, M. The employment footprints of nations. J. Ind. Ecol. 2014, 18, 59-70. [CrossRef]

28. Simas, M.; Wood, R.; Hertwich, E. Labor embodied in trade. J. Ind. Ecol. 2014, 19, 343-356. [CrossRef]

29. Bunker, S.G. Underdeveloping the Amazon: Extraction, Unequal Exchange, and the Failure of the Modern State; University of Chicago Press: Chicago, IL, USA, 1985; ISBN 978-0-226-08032-1.

30. Wallerstein, I.M. World-Systems Analysis: An Introduction; Duke University Press: Durham, NC, USA, 2004; ISBN 0-8223-3442-9.

31. Haberl, H. Competition for land: A sociometabolic perspective. Ecol. Econ. 2015, 119, 424-431. [CrossRef]

32. Land Use Competition. Ecological, Economic and Social Perspectives. In Ecological, Economic and Social Perspectives; Niewöhner, J., Bruns, A., Hostert, P., Krueger, T., Østergaard Nielsen, J., Haberl, H., Lauk, C., Lutz, J., Müller, D., Eds.; Springer International Publishing: Cham, Switzerland, 2016; Volume 6, ISBN 978-3-319-33626-8.

33. Smith, P.; Gregory, P.J.; van Vuuren, D.; Obersteiner, M.; Havlík, P.; Rounsevell, M.; Woods, J.; Stehfest, E.; Bellarby, J. Competition for land. Philos. Trans. R. Soc. B Biol. Sci. 2010, 365, 2941-2957. [CrossRef] [PubMed]

34. Steffen, W.; Richardson, K.; Rockström, J.; Cornell, S.E.; Fetzer, I.; Bennett, E.M.; Biggs, R.; Carpenter, S.R.; de Vries, W.; de Wit, C.A.; et al. Planetary boundaries: Guiding human development on a changing planet. Science 2015, 1259855. [CrossRef] [PubMed]

35. Pichler, M.; Schaffartzik, A.; Haberl, H.; Görg, C. Drivers of society-nature relations in the Anthropocene and their implications for sustainability transformations. Curr. Opin. Environ. Sustain. 2017, 26-27, 32-36. [CrossRef]

36. Malm, A. Fossil Capital: The Rise of Steam Power and the Roots of Global Warming; Verso Books: New York, NY, USA, 2016; ISBN 1-78478-130-4.

37. Mitchell, T. Carbon Democracy: Political Power in the Age of Oil; Verso Books: New York, NY, USA, 2011; ISBN 1-84467-745-1. 
38. Beckert, S. Empire of Cotton: A Global History; Knopf Doubleday Publishing Group: New York, NY, USA, 2014; ISBN 978-0-385-35325-0.

39. Steffen, W.; Broadgate, W.; Deutsch, L.; Gaffney, O.; Ludwig, C. The trajectory of the Anthropocene: The Great Acceleration. Anthr. Rev. 2015, 2053019614564785. [CrossRef]

40. Haberl, H.; Mbow, C.; Deng, X.; Irwin, E.G.; Kerr, S.; Kuemmerle, T.; Mertz, O.; Meyfroidt, P.; Turner, B.L., II. Finite Land Resources and Competition. In Rethinking Global Land Use in an Urban Era; MIT Press: Cambridge, MA, USA, 2014; pp. 33-67.

41. Gonzalez-Hidalgo, M.; Zografos, C. How sovereignty claims and "negative" emotions influence the process of subject-making: Evidence from a case of conflict over tree plantations from Southern Chile. Geoforum 2017, 78, 61-73. [CrossRef]

42. Himley, M. Regularizing Extraction in Andean Peru: Mining and Social Mobilization in an Age of Corporate Social Responsibility. Antipode 2013, 45, 394-416. [CrossRef]

43. Hall, D.; Hirsch, P.; Li, T.M. Powers of Exclusion. In Land Dilemmas in Southeast Asia; NUS Press: Singapore, 2011.

44. Peluso, N.L. Seeing property in land use: Local territorializations in West Kalimantan, Indonesia. Geogr. Tidsskr. Dan. J. Geogr. 2005, 105, 1-15. [CrossRef]

45. Camba, A.A. From colonialism to neoliberalism: Critical reflections on Philippine mining in the "long twentieth century". Extr. Ind. Soc. Int. J. 2015, 2, 287-301. [CrossRef]

46. Alonso-Fradejas, A. Anything but a story foretold: Multiple politics of resistance to the agrarian extractivist project in Guatemala. J. Peasant Stud. 2015, 42, 489-515. [CrossRef]

47. Alonso-Fradejas, A. Land control-grabbing in Guatemala: The political economy of contemporary agrarian change. Can. J. Dev. Stud. 2012, 33, 509-528. [CrossRef]

48. Li, T.M. To Make Live or Let Die? Rural Dispossession and the Protection of Surplus Populations. Antipode 2010, 41, 66-93. [CrossRef]

49. Silva-Macher, J.C.; Farrell, K.N. The flow / fund model of Conga: Exploring the anatomy of environmental conflicts at the Andes-Amazon commodity frontier. Environ. Dev. Sustain. 2014, 16, 747-768. [CrossRef]

50. Sugden, F.; Punch, S. Capitalist expansion and the decline of common property ecosystems in China, Vietnam and India. Dev. Chang. 2014, 45, 656-684. [CrossRef]

51. Cernea, M.M.; Schmidt-Soltau, K. Poverty risks and national parks: Policy issues in conservation and resettlement. World Dev. 2006, 34, 1808-1830. [CrossRef]

52. Hein, J.; Faust, H. Conservation, REDD+ and the struggle for land in Jambi, Indonesia. Pac. Geogr. 2014, 41, 20-25.

53. MacDonald, T.; Winklerprins, A.M.G.A. Searching for a better life: Peri-urban migration in western para state, Brazil. Geogr. Rev. 2014, 104, 294-309. [CrossRef]

54. Maconachie, R. Dispossession, exploitation or employment? Youth livelihoods and extractive industry investment in Sierra Leone. Futures 2014, 62, 75-82. [CrossRef]

55. Peluso, N.L.; Humphrey, C.R.; Fortmann, L.P. the rock, the beach, and the tidal pool-People and poverty in natural resource-dependent areas. Soc. Nat. Resour. 1994, 7, 23-38. [CrossRef]

56. Laurance, W.F.; Peletier-Jellema, A.; Geenen, B.; Koster, H.; Verweij, P.; van Dijck, P.; Lovejoy, T.E.; Schleicher, J.; van Kuijk, M. Reducing the global environmental impacts of rapid infrastructure expansion. Curr. Biol. 2015, 25, R259-R262. [CrossRef] [PubMed]

57. Munive, J. A political economic history of the Liberian state, forced labour and armed mobilization. J. Agrar. Chang. 2011, 11, 357-376. [CrossRef]

58. Barber, L. Construction-phase extended commuting and uneven regional development: Work, households and communities in Newfoundland and Labrador's new extractive economy. Extr. Ind. Soc. Int. J. 2016, 3, 640-648. [CrossRef]

59. Carrington, W.J. The Alaskan Labor Market during the Pipeline Era. J. Political Econ. 1996, 104, $186-218$. [CrossRef]

60. Bell, S.E.; York, R. Community Economic Identity: The Coal Industry and Ideology Construction in West Virginia. Rural Sociol. 2010, 75, 111-143. [CrossRef]

61. Greenberg, P. Disproportionality and resource-based environmental inequality: An analysis of neighborhood proximity to coal impoundments in appalachia. Rural Sociol. 2017, 82, 149-178. [CrossRef] 
62. Labban, M. Against Value: Accumulation in the oil industry and the biopolitics of labour under finance. Antipode 2014, 46, 477-496. [CrossRef]

63. Paredes, D.; Komarek, T.; Loveridge, S. Income and employment effects of shale gas extraction windfalls: Evidence from the Marcellus region. Energy Econ. 2015, 47, 112-120. [CrossRef]

64. Thistle, J. Forgoing full value? Iron ore mining in Newfoundland and Labrador, 1954-2014. Extr. Ind. Soc. Int. J. 2016, 3, 103-116. [CrossRef]

65. McKay, B.M. Agrarian Extractivism in Bolivia. World Dev. 2017, 97, 199-211. [CrossRef]

66. Rettberg, A. Global markets, local conflict violence in the colombian coffee region after the breakdown of the international coffee agreement. Lat. Am. Perspect. 2010, 37, 111-132. [CrossRef]

67. Oglesby, E. Corporate citizenship? Elites, labor, and the geographies of work in Guatemala. Environ. Plan. Soc. Space 2004, 22, 553-572. [CrossRef]

68. Katz, C. Dualities of Latin America. Lat. Am. Perspect. 2015, 42, 10-42. [CrossRef]

69. Vincent, S. Pensions, Peasants, and the Informal Economy: Family and Livelihood in Contemporary Peru. Lat. Am. Perspect. 2018, 45, 195-211. [CrossRef]

70. McCarthy, J.F.; Gillespie, P.; Zen, Z. Swimming upstream: Local Indonesian production networks in "globalized" palm oil production. World Dev. 2012, 40, 555-569. [CrossRef]

71. Walia, H. Transient servitude: Migrant labour in Canada and the apartheid of citizenship. Race Cl. 2010, 52, 71-84. [CrossRef]

72. Pye, O.; Daud, R.; Harmono, Y. Tatat Precarious lives: Transnational biographies of migrant oil palm workers: Precarious lives: Migrant palm oil workers. Asia Pac. Viewp. 2012, 53, 330-342. [CrossRef]

73. Martinus, K. Regional development in a resource production system: Long distance commuting, population growth, and wealth redistribution in the Western Australia Goldfields. Geogr. Res. 2016, 54, 420-432. [CrossRef]

74. Lockie, S.; Franettovich, M.; Petkova-Timmer, V.; Rolfe, J.; Ivanova, G. Coal mining and the resource community cycle: A longitudinal assessment of the social impacts of the Coppabella coal mine. Environ. Impact Assess. Rev. 2009, 29, 330-339. [CrossRef]

75. Leite, C.A.; Weidmann, J. Does Mother Nature Corrupt? Natural Resources, Corruption, and Economic Growth; IMF Working Papers; International Monetary Fund: Washington, DC, USA, 1999; Volume 85, ISBN 978-1-4518-5073-4.

76. Smith, G. Nupela Masta? Local and Expatriate Labour in a Chinese-Run Nickel Mine in Papua New Guinea. Asian Stud. Rev. 2013, 37, 178-195. [CrossRef]

77. Tetreault, D. Free-Market Mining in Mexico. Crit. Sociol. 2016, 42, 643-659. [CrossRef]

78. Walker, K.L.M. From covert to Overt: Everyday peasant politics in China and the implications for transnational agrarian movements. J. Agrar. Chang. 2008, 8, 462-488. [CrossRef]

79. Zockun, M.H.G.P. A expansão da Soja no Brasil: Alguns Aspectos da Produção; Instituto de Pesquisas Econômicas da Faculdade de Economia e Administração da Universidade de São Paulo: Sao Paulo, Brazil, 1980.

80. Fearnside, P.M. Soybean cultivation as a threat to the environment in Brazil. Environ. Conserv. 2001, 28, 23-38. [CrossRef]

81. Weber, J.G. The effects of a natural gas boom on employment and income in Colorado, Texas, and Wyoming. Energy Econ. 2012, 34, 1580-1588. [CrossRef]

82. Kojola, E. (Re)constructing the Pipeline: Workers, Environmentalists and Ideology in Media Coverage of the Keystone XL Pipeline. Crit. Sociol. 2017, 43, 893-917. [CrossRef]

83. Freudenburg, W.R.; Wilson, L.J. Mining the Data: Analyzing the Economic Implications of Mining for Nonmetropolitan Regions. Sociol. Inq. 2003, 72, 549-575. [CrossRef]

84. Komarek, T.M. Labor market dynamics and the unconventional natural gas boom: Evidence from the Marcellus region. Resour. Energy Econ. 2016, 45, 1-17. [CrossRef]

85. Fleming, D.A.; Measham, T.G. Income Inequality across Australian Regions during the Mining Boom: 2001-2011. Aust. Geogr. 2015, 46, 203-216. [CrossRef]

86. Freudenburg, W.; Gramling, R. Linked to what? Economic linkages in an extractive economy. Soc. Nat. Resour. 1998, 11, 569-586. [CrossRef]

87. Havens, A.E.; Flinn, W.L. Internal Colonialism and Structural Change in Colombia; Praeger Publishers: New York, NY, USA, 1970.

88. Evensen, D.; Stedman, R. 'Fracking': Promoter and destroyer of 'the good life'. J. Rural Stud. 2018, 59, 142-152. [CrossRef] 
89. Bebbington, A.; Hinojosa, L.; Bebbington, D.H.; Burneo, M.L.; Warnaars, X. Contention and ambiguity: Mining and the possibilities of development. Dev. Chang. 2008, 39, 887-914. [CrossRef]

90. McGrath, S. Fuelling global production networks with slave labour? Migrant sugar cane workers in the Brazilian ethanol GPN. Geoforum 2013, 44, 32-43. [CrossRef]

91. Goldenberg, S.M.; Shoveller, J.A.; Koehoorn, M.; Ostry, A.S. And they call this progress? Consequences for young people of living and working in resource-extraction communities. Crit. Public Health 2010, 20, 157-168. [CrossRef]

92. Pegg, S. Mining and poverty reduction: Transforming rhetoric into reality. J. Clean. Prod. 2006, 14, $376-387$. [CrossRef]

93. Singh, J.T.N. Reconstituting the Neostructuralist State: The political economy of continuity and change in Chilean mining policy. Third World Q. 2010, 31, 1413-1433. [CrossRef]

94. Arsel, M.; Hogenboom, B.; Pellegrini, L. The extractive imperative in Latin America. Extr. Ind. Soc. Int. J. 2016, 3, 880-887. [CrossRef]

95. Scanlan, S.J. Framing fracking: Scale-shifting and greenwashing risk in the oil and gas industry. Local Environ. 2017, 22, 1311-1337. [CrossRef]

96. Schaffartzik, A.; Brad, A.; Pichler, M.; Plank, C. At a Distance from the Territory: Distal Drivers in the (Re)territorialization of Oil Palm Plantations in Indonesia. In Land Use Competition. Ecological, Economic and Social Perspectives; Niewöhner, J., Bruns, A., Hostert, P., Krüger, T., Nielsen, J.Ø., Haberl, H., Lauk, C., Lutz, J., Müller, D., Eds.; Springer International Publishing: Cham, Switzerland, 2016; ISBN 978-3-319-33626-8.

97. Niewöhner, J.; Nielsen, J.Ø.; Gasparri, I.; Gou, Y.; Hauge, M.; Joshi, N.; Schaffartzik, A.; Sejersen, F.; Seto, K.C.; Shughrue, C. Conceptualizing Distal Drivers in Land Use Competition. In Land Use Competition; Niewöhner, J., Bruns, A., Hostert, P., Krueger, T., Nielsen, J.Ø., Haberl, H., Lauk, C., Lutz, J., Müller, D., Eds.; Human-Environment Interactions; Springer International Publishing: Cham, Switzerland, 2016; pp. 21-40, ISBN 978-3-319-33626-8.

98. Schaffartzik, A.; Brad, A.; Pichler, M. A world away and close to home: The multi-scalar 'making of' Indonesia's energy landscape. Energy Policy 2017, 109, 817-824. [CrossRef]

99. Walker, J. Creating an LNG ready worker: British Columbia's blueprint for extraction education. Glob. Soc. Educ. 2018, 16, 78-92. [CrossRef]

100. Howe, C.; Boyer, D. Aeolian extractivism and community wind in Southern Mexico. Public Cult. 2016, 28, 215-235. [CrossRef]

101. Sovacool, B.K.; Bulan, L.C. They'll be dammed: The sustainability implications of the Sarawak Corridor of Renewable Energy (SCORE) in Malaysia. Sustain. Sci. 2013, 8, 121-133. [CrossRef]

102. Li, F. Unearthing Conflict: Corporate Mining, Activism, and Expertise in Peru; Duke University Press: Durham, NC, USA, 2015; ISBN 978-0-8223-5819-0.

(C) 2018 by the author. Licensee MDPI, Basel, Switzerland. This article is an open access article distributed under the terms and conditions of the Creative Commons Attribution (CC BY) license (http://creativecommons.org/licenses/by/4.0/). 